\title{
SNP haplotyping technique for evaluation of MGP 5' UTR power in osteoblast cells
}

\author{
Abazar Roustazadeh', Seyed Hamidreza Monavari ${ }^{3}$, Seyed Reza Hosseini Fard ${ }^{4}$, Parisa Hassanpour ${ }^{4}$, \\ Amaneh Yarnazari ${ }^{4}$ and Mohammad Najafi ${ }^{2,4^{*}}$
}

*Correspondence:

nbsmmsbn@iums.ac.ir

${ }^{2}$ Cellular and Molecular

Research Center, Iran

University of Medical

Sciences, Tehran, Iran

Full list of author information

is available at the end of the article

\begin{abstract}
Matrix Gla protein (MGP) is involved in calcium trafficking and arterial calcification. The aim of study was to investigate the role of three polymorphisms within the MGP gene promoter region on reporter gene (luciferase) expression level. The fragments containing rs 1800799 (C/T), rs1800802 (T/C), and rs1800801 (G/A) sites were constructed and transferred into human G292 osteoblast cells using pGL3-Basic plasmid. The reporter gene expression was calculated for the high and low frequency polymorphic haplotypes (CTG and TCA, respectively). Results showed that the reporter gene expression levels are not statistically different $(p>0.3)$. We concluded that the investigated polymorphic sites are not able to change the gene expression pattern in human G292 osteoblast cells.
\end{abstract}

Keywords: Haplotype, Matrix Gla protein (MGP), Single nucleotide polymorphism (SNP), Osteoblast, Promoter

\section{Background}

Vascular mineralization is a passive end-stage process in stenosis of arteries (Schurgers et al. 2013). Vitamin K-dependent matrix Gla protein (MGP) is known a calcium scavenger and may play a dominant role in vascular calcium metabolism. It is a mineral-binding extracellular matrix (ECM) protein mostly expressed by vascular smooth muscle cells (VSMCs), osteoblasts and chondrocytes. It is generally believed as potent inhibitor of arterial calcification (Schurgers et al. 2008). A study showed that MGP knockout $\left(\mathrm{MGP}^{-1-}\right)$ mice developed blood vessel rupture and died due to arterial calcification after 2 months (Luo et al. 1997). The MGP gene (Entrez; Gene ID: 4256) is located on the short arm of chromosome 12 (12p12.3). dbSNP data (www.ncbi.nlm.nih.gov/snp) showed that polymorphic sites are widely distributed in the different regions of MGP gene and are potentially related to the MGP function (Farzaneh-Far et al. 2001). Furthermore, the MGP rs1800801 and rs1800802 promoter-reporter gene constructs showed that the rs $1800802 C$ allele consistently reduces promoter activity in vascular smooth muscle cells (Herrmann et al. 2000).

Although haplotype blocks are referred as variant distributions in several loci but we defined the haplotypes based on the distribution of polymorphisms within transcription factor elements located separately on the MGP promoter. In previous study, we

(c) 2016 The Author(s). This article is distributed under the terms of the Creative Commons Attribution 4.0 International License (http://creativecommons.org/licenses/by/4.0/), which permits unrestricted use, distribution, and reproduction in any medium, provided you give appropriate credit to the original author(s) and the source, provide a link to the Creative Commons license, and indicate if changes were made. 
predicted the high minimal allele frequency (MAF) polymorphic scores for each transcription factor element and showed that the rs1800801, rs1800802 and rs1800799 haplotypes within the MGP promoter did not relate to stenosis of coronary arteries. Moreover, serum MGP concentration was not associated to the genotype and haplotype distributions (Najafi et al. 2014). In this study, we followed our investigations and focused on the promoter expression power using polymorphic constructs in human MGP high expressed G292 osteoblast cells.

\section{Methods}

\section{High and low frequent haplotype constructs}

The haplotype constructs (TCA and CTG) were obtained by direct haplotyping with ARMS and RFLP-PCR methods as reported in the previous study (Najafi et al. 2014). At first, the amplified two-allele fragments containing the rs1800802 heterozygote were separated by ARMS-PCR technique at the rs 1800801 position. The ARMS-PCR reactions were performed in two microtubes $(25 \mu \mathrm{l})$ containing $\mathrm{MgCl}_{2}(1.5 \mathrm{mM})$, Hot-start Taq plus DNA polymerase (1.25 U), genomic DNA $(0.2 \mu \mathrm{g})$, Common Primer $(1 \mu \mathrm{M}$; 5'-AGTGGAACAACCGCCAGTCTCATTAG-3') and Allele Specific (AS) Primers (1 $\mu \mathrm{M} ; 5^{\prime}$-GCAGCAGTAGGGAGAGAGGCTCCTAC-3' and $5^{\prime}$-GCAGCAGTAGG GAGAGAGGCTCCTAT- $\left.3^{\prime}\right)$. The temperature cycles $(\mathrm{n}=30)$ were followed after incubation at $95{ }^{\circ} \mathrm{C}$ for $5 \min \left(95{ }^{\circ} \mathrm{C}\right.$ for $30 \mathrm{~s}, 68^{\circ} \mathrm{C}$ for $50 \mathrm{~s}$ and $72{ }^{\circ} \mathrm{C}$ for $\left.90 \mathrm{~s}\right)$ and a final extension at $72{ }^{\circ} \mathrm{C}$ for $7 \mathrm{~min}$. Then, each allele was amplified with the designed forward and reverse primers to insert the digestible elements within constructs based on the previous PCR condition (Fig. 1).

\section{DNA cloning}

\section{Digestion and ligation}

The haplotype constructs were digested with SspI (NEB; Cat. No. R0132L, 10 U, overnight) and HindIII (NEB; Cat. No. R0104S, 8 U, overnight) restriction enzymes. Then, the fragments were evaluated on agarose gel $3.5 \%(\mathrm{w} / \mathrm{v})$. The pGL3-Basic plasmid (Promega; AC U47295) was also digested by SmaI (NEB; Cat. No. RO141L, 10 U, overnight) and HindIII (8 U, overnight) enzymes (Fig. 2).

Rapid DNA dephose and ligation kit (Roche; Cat. No. 11635379 001) was used for the ligation of fragments at the upstream region of reporter gene. The results were confirmed on agarose gel $2 \%$ (w/v). Briefly, $1 \mu \mathrm{l}$ (200-300 ng) of pGL3-Basic plasmid, $1 \mu \mathrm{l}$ of fragment (20-50 ng), $10 \mu \mathrm{l}$ of T4 DNA ligation buffer and $1.5 \mu \mathrm{l}$ of T4 DNA ligase (7.5 $\mathrm{U})$ were gently mixed and incubated for $30 \mathrm{~min}$ at room temperature followed up to $24 \mathrm{~h}$ at $16^{\circ} \mathrm{C}$ (Figs. 1, 2).

\section{Cell culture}

The human G292 osteoblast cells were harvested in Dulbecco's modified Eagle's medium (DMEM) supplemented with $5 \%(\mathrm{v} / \mathrm{v})$ fetal bovine serum (FBS) at $37{ }^{\circ} \mathrm{C}$ in a humidified $\mathrm{CO} 2$ atmosphere $5 \%$. The plasmid transfection was conducted by X-tremeGENE HP DNA transfection reagent (Roche; Cat. No. 06366244001) to introduce plasmids into cells essentially. They were transferred into 6-well plates (confluency; $70 \%$ ) and, were exposed for $4 \mathrm{~h}$ with $200 \mu \mathrm{l}$ of transfection complex $(2 \mu \mathrm{g}$ of constructed plasmid and 


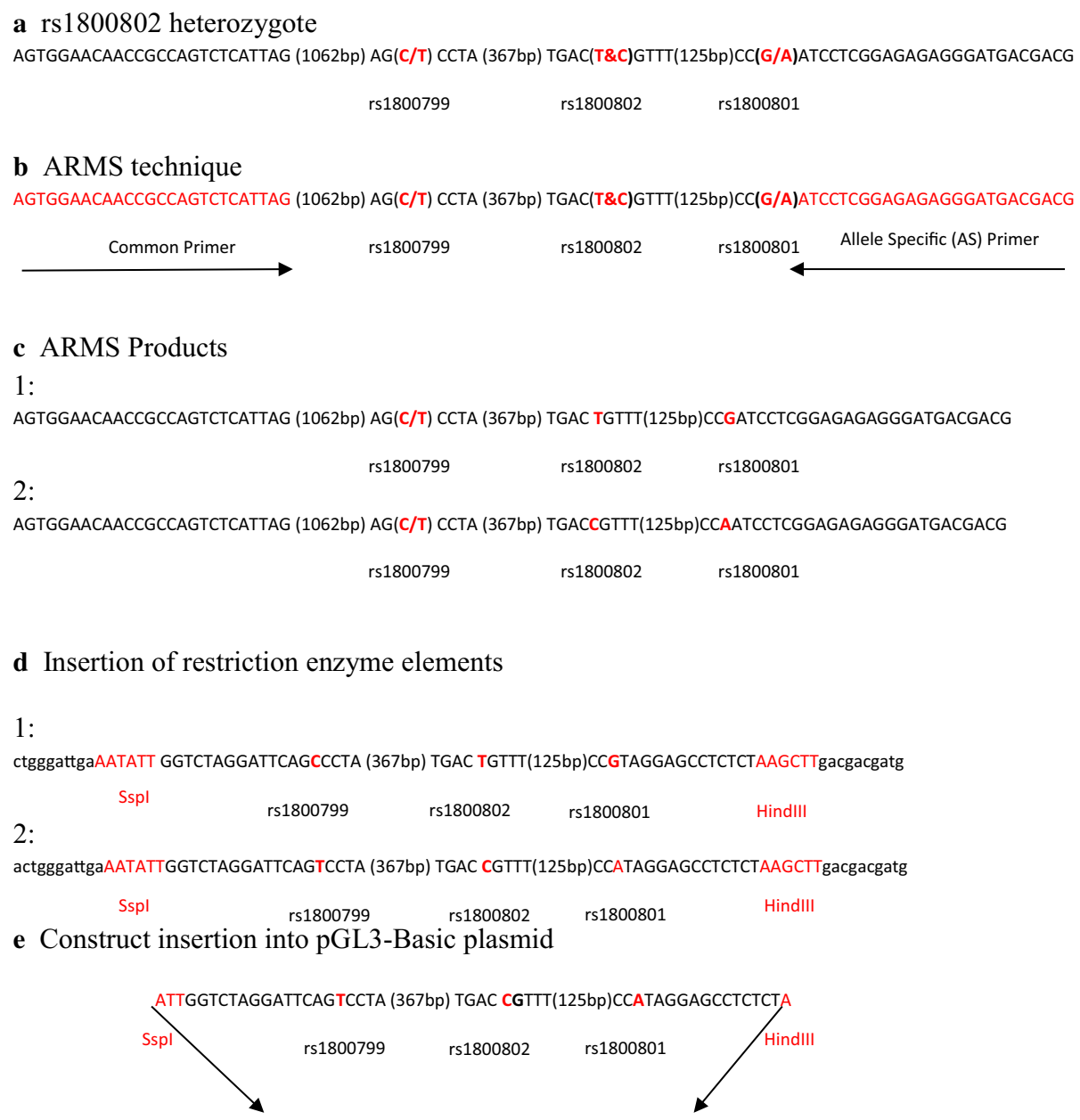

pGL3:Basic

Fig. 1 Construct preparation and plasmid insertion

$6 \mu \mathrm{l} \mathrm{X}$-tremeGENE). Then, the transfected cells ( 2 millions) were treated with phorbol 12-myristate 13-acetate (Sigma; Cat. No. P8139) for $2 \mathrm{~h}$ and, were grown for $24 \mathrm{~h}$.

\section{RNA extraction and CDNA synthesis}

Total RNA was isolated from the plasmid-transfected cells using HP RNA isolation kit (Roche; Cat. No. 11828665 001) as described by the manufacturer's instructions. Genomic DNA was eliminated by DNase I during the extraction procedure. Briefly, the cells were washed three times using cold phosphate-buffered saline solution (PBS) and, were harvested in $400 \mu \mathrm{l}$ of lysis-binding buffer followed by centrifugation to remove 


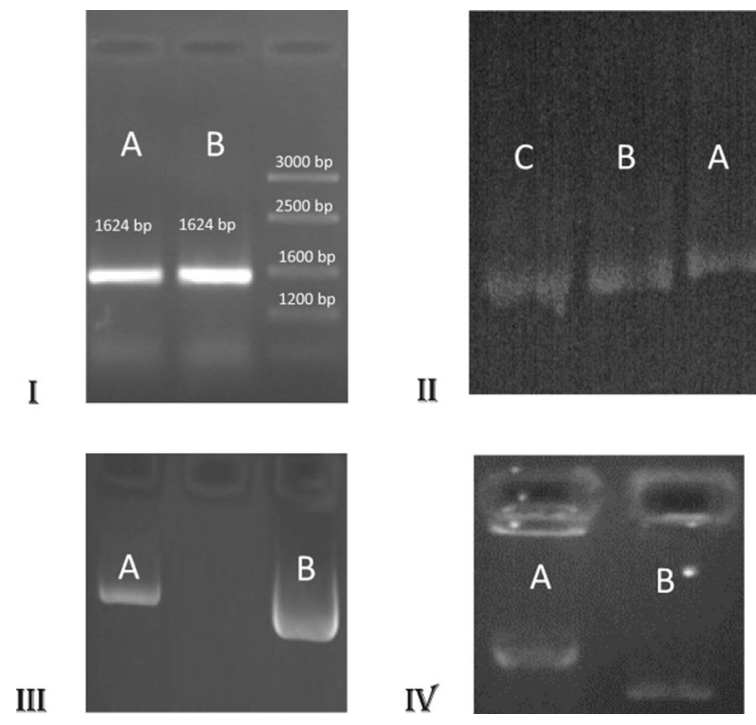

Fig. 2 pGL3 Basic plasmid and constructs on agarose gel. I ARMS products; the ARMS-PCR reactions were performed in two microtubes and the products (1624 bp) were run on the agarose gel $(2 \%)$ electrophoresis (Lanes $A, B$ and Ladder). II Constructs containing three polymorphic sites were digested using restriction enzymes (REs) and were run on the agarose gel (3.5\%) electrophoresis ( $A$ amplified product, 568 bp, $B$ digestion with Sspl, 555 bp, C digestion with Sspl and Hindlll, 540 bp). III pGL3 Basic plasmid was digested using restriction enzymes (Smal and HindIII) and was run on the agarose gel (2\%) electrophoresis ( $A$ intact plasmid, $B$ digested plasmid with REs). IV The REs-digested constructs (539 bp) were inserted and ligated into pGL3 Basic plasmid and were compared on the agarose gel (2\%) (A construct-inserted plasmid, $B$ intact plasmid)

cellular debris. Then, wash buffer $(400 \mu \mathrm{l})$ was added and centrifuged. After adding $50 \mu \mathrm{l}$ of elution buffer, RNA was stored at $-80^{\circ} \mathrm{C}$.

cDNA synthesis was carried out with QuantiTect Reverse Transcription kit (Qiagen; Cat. No. 205310) using random primers in a total volume of $20 \mu$ l. Quality of cDNA was tested through PCR reaction.

\section{Real-time qPCR technique}

The luciferase expression level was measured with QuantiFast SYBER Green PCR kit (Qiagen; Cat. No. 204054) using specific primers (0.5 $\mu \mathrm{M}$ each). The reporter gene was located in the downstream of pGL3-Basic plasmid-inserted haplotype constructs and was not able to express in the cell model. The primers were designed by Genamics Expression software. Furthermore, the beta-actin (ACTB) gene was applied as endogenous gene (Table 1).

The temperature cycles $(\mathrm{n}=40)$ for luciferase gene were followed after incubation at $95{ }^{\circ} \mathrm{C}$ for $5 \mathrm{~min}\left(95^{\circ} \mathrm{C}\right.$ for $10 \mathrm{~s}, 68^{\circ} \mathrm{C}$ for $15 \mathrm{~s}$ and $72{ }^{\circ} \mathrm{C}$ for $\left.15 \mathrm{~s}\right)$. Also, the temperature cycles $(\mathrm{n}=40)$ for ACTB gene were followed after incubation at $95{ }^{\circ} \mathrm{C}$ for $5 \min \left(95^{\circ} \mathrm{C}\right.$ for $15 \mathrm{~s}, 67{ }^{\circ} \mathrm{C}$ for $15 \mathrm{~s}$ and $72{ }^{\circ} \mathrm{C}$ for $15 \mathrm{~s}$ ). Standard curves were composed of tenfold dilutions and, melting curves ranged from 65 to $95^{\circ} \mathrm{C}$ by steps of $0.5^{\circ} \mathrm{C}$ were performed to evaluate non-specific products. 
Table 1 Primers used for RT-qPCR reaction

\begin{tabular}{llc}
\hline Primer & Sequence & $\mathbf{T}_{\text {annealing }}$ \\
\hline F-luciferase & 5'-CATAGCTTCTGCCAACCGAACG-3' $^{\prime}$ & \\
R-luciferase & 5'-GGAAGATGGAACCGCTGGAGAG-3' & 68 \\
F-ACTB & 5'-GCGAGAAGATGACCCAGATCATG-3' \\
R-ACTB & 5'-CGTCACCGGAGTCCATCACG-3' & 67 \\
\hline
\end{tabular}

\section{Statistical analysis}

Statistical analysis was performed using statistical software package (SPSS 18, Chicago). Relative expression was measured and tested according to Pfaffl formula $\left(2^{-\triangle C T}\right)$. The expression levels from CTG ( $n=6$ wells) and from TCA ( $n=6$ wells) cell cultures were compared using Mann-Whitney U test. p Value $<0.05$ was considered to be significant.

\section{Results}

TCA and CTG haplotypes (rs1800799, rs1800802 and rs1800801) were successfully constructed by the PCR techniques. The construct and insertion results were correctly considered on the agarose gel. The pGL3-Basic construct-inserted plasmids were transferred into osteoblast cells and, were subjected for reporter gene expression. The results showed that the relative expression of reporter gene (CTG $1.5 \pm 0.4$; TCA $1.2 \pm 0.2$ ) was not significantly different ( $\mathrm{p}>0.3$ ). The findings showed that CTG and TCA haplotypes cannot functionality affect the expression patterns in human G292 osteoblast cells (Fig. 3).

\section{Discussion}

Matrix Gla protein (84 aa, $14 \mathrm{kDa}$ ) is a secretary protein containing five $\gamma$-carboxyglutamic acid (Gla) residues originally isolated from bone (Schurgers et al. 2013). Its expression is also reported in other tissues including kidney, lung, heart and cartilage. Studies have also been reported the MGP gene expression in vascular smooth muscle cells (VSMCs), endothelial cells (ECs) and fibroblasts (Price et al. 1976).

In vitro studies revealed that the rs1800801 A variant had an approximately 1.5-fold higher activity than G variant in VSMCs (Farzaneh-Far et al. 2001). Herrmann et al.

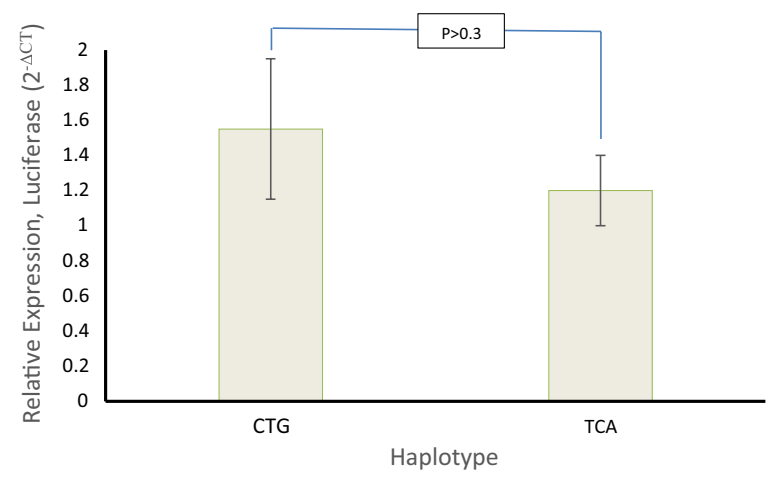

Fig. 3 Relative expression level between high and low frequency haplotypes 
carried out transient transfection experiments with allele promoter-reporter gene constructs and DNA-protein interaction assays to investigate the functionality of promoter rs1800802 and rs1800801 variants. The minor rs $1800802 \mathrm{C}$ allele consistently conferred a reduced promoter activity of $20 \%$ in rat vascular smooth muscle cells and of $50 \%$ in a human fibroblast cell line whereas the other polymorphisms including rs1800801 displayed no evidence of in vitro functionality (Herrmann et al. 2000). The relationships were inconsistent and limited to independent roles of polymorphic sites. It was necessary to show the additive effects on transcription factor elements if there is any association between the mentioned polymorphic sites. In agreement with others (Farzaneh-Far et al. 2001; Crosier et al. 2009) and our previous report (Najafi et al. 2014), the population studies showed no difference between MGP concentration and promoter polymorphic variants. We also didn't find the association between serum MGP concentrations and two-allele haplotypes in population using direct haplotyping and prediction tools. We confined our study to dominant and recessive haplotypes to show whether there is any association between polymorphic sites and also their phenotypes using transient transfection experiments. Other polymorphic sites present in promoter region might affect the gene expression patterns, potentially present also in our constructs, which have not the same genetic background of the haplotypes found in the population. However, these variants are present also in the control constructs. We aimed in fact to verify the differences in expression patterns due to the three SNPs, to test whether they are functional and the responsible of the phenotypic variability observed in the population. Although the dominant haplotype (CTG) showed slightly a higher expression than the recessive haplotype (TCA), the difference was not statistically significant. These results supported the population and prediction studies that the allele changes within the elements could not significantly affect the functionality of the promoter.

\section{Conclusions}

We concluded that the high and low frequent polymorphic haplotypes within MGP promoter region have not the effect on functionality of promoter and, could not significantly affect the phenotype.

Authors' contributions

$\mathrm{AR}$ and MN designed the study. AR and SHM performed the experiments. SRH, PH and AY supervised and supported the work. All authors read and approved the final manuscript.

Author details

${ }^{1}$ Research Center for Non-Communicable Diseases and Biochemistry Department, Jahrom University of Medical Sciences, Jahrom, Iran. ${ }^{2}$ Cellular and Molecular Research Center, Iran University of Medical Sciences, Tehran, Iran. ${ }^{3}$ Virology Department, Iran University of Medical Sciences, Tehran, Iran. ${ }^{4}$ Biochemistry Department, Iran University of Medical Sciences, Tehran, Iran.

Acknowledgements

The authors like to thank all the people who have helped in this study and taken the time to share their experiences with us.

Competing interests

The authors declare that they have no competing interests.

Received: 21 September 2015 Accepted: 11 May 2016

Published online: 13 June 2016 


\section{References}

Crosier MD, Booth SL, Peter I, Dawson-Hughes B, Price PA, O'Donnell CJ, Hoffmann U, Williamson MK, Ordovas JM (2009)

Matrix Gla protein polymorphisms are associated with coronary artery calcification in men. J Nutr Sci Vitaminol (Tokyo) 55:59-65

Farzaneh-Far A, Davies JD, Braam LA, Spronk HM, Proudfoot D, Chan SW, O'Shaughnessy KM, Weissberg PL, Vermeer C, Shanahan CM (2001) A polymorphism of the human matrix gamma-carboxyglutamic acid protein promoter alters binding of an activating protein-1 complex and is associated with altered transcription and serum levels. J Biol Chem 276:32466-32473

Herrmann SM, Whatling C, Brand E, Nicaud V, Gariepy J, Simon A, Evans A, Ruidavets JB, Arveiler D, Luc G, Tiret L, Henney A, Cambien F (2000) Polymorphisms of the human matrix gla protein (MGP) gene, vascular calcification, and myocardial infarction. Arterioscler Thromb Vasc Biol 20:2386-2393

Luo G, Ducy P, McKee MD, Pinero GJ, Loyer E, Behringer RR, Karsenty G (1997) Spontaneous calcification of arteries and cartilage in mice lacking matrix GLA protein. Nature 386:78-81

Najafi M, Roustazadeh A, Amirfarhangi A, Kazemi B (2014) Matrix Gla protein (MGP) promoter polymorphic variants and its serum level in stenosis of coronary artery. Mol Biol Rep 41:1779-1786

Price PA, Otsuka AA, Poser JW, Kristaponis J, Raman N (1976) Characterization of a gamma-carboxyglutamic acid-containing protein from bone. Proc Natl Acad Sci USA 73:1447-1451

Schurgers LJ, Cranenburg EC, Vermeer C (2008) Matrix Gla-protein: the calcification inhibitor in need of vitamin K. Thromb Haemost 100:593-603

Schurgers LJ, Uitto J, Reutelingsperger CP (2013) Vitamin K-dependent carboxylation of matrix Gla-protein: a crucial switch to control ectopic mineralization. Trends Mol Med 19:217-226

\section{Submit your manuscript to a SpringerOpen ${ }^{\circ}$ journal and benefit from:}

- Convenient online submission

- Rigorous peer review

- Immediate publication on acceptance

- Open access: articles freely available online

- High visibility within the field

- Retaining the copyright to your article

Submit your next manuscript at $>$ springeropen.com 